\title{
Medium-sized and large mammals of the pine-oak forests and grasslands of the Rancho Experimental Teseachi in Chihuahua, Mexico
}

\author{
Fernando Álvarez-Córdova ${ }^{1}$ Jesús A. Fernández ${ }^{1,2^{*}}$ \\ 1 Maestría en Producción Animal y Recursos Naturales, Departamento de Recursos Naturales, Facultad de Zootecnia y Ecología, Universidad \\ Autónoma de Chihuahua, Chihuahua, México•FAC: biofer.alva@gmail.com (Dttps://orcid.org/0000-0002-8104-4317•JAF: afernandezf@ \\ uach.mx (1) https://orcid.org/0000-0003-3949-5234 \\ 2 Departamento de Recursos Naturales, Facultad de Zootecnia y Ecología, Universidad Autónoma de Chihuahua, Chihuahua, México \\ * Corresponding author
}

\begin{abstract}
We document the taxonomic diversity of medium-sized and large mammals present in Rancho Experimental Teseachi, a teaching and research facility of the Universidad Autónoma de Chihuahua located in the northwestern part of Chihuahua, Mexico. Monthly samplings were made with lineal transects of $5 \mathrm{~km}$ in two habitats, open grassland and pine-oak forest, where camera-traps and scent-stations were placed, and tracks were searched. Sixteen species of medium-sized and large mammals were recorded in the area, representing $12.03 \%$ of the state's diversity. The greatest diversity was found in the pine-oak forest. Implementing three different sampling techniques at the same time allows the documentation of mammal diversity more efficiently than using only one or two sampling techniques.
\end{abstract}

\section{Keywords}

Biological inventory, Carnivora, diversity, ecosystems, Lagomorpha, Rodentia

Academic editor: Guilherme Garbino | Received 5 December 2020 | Accepted 25 March 2021 | Published 20 April 2021

Citation: Álvarez-Córdova F, Fernández JA (2021) Medium-sized and large mammals of the pine-oak forests and grasslands of the Rancho Experimental Teseachi in Chihuahua, Mexico. Check List 17 (2): 669-681. https://doi.org/10.15560/17.2.669

\section{Introduction}

Medium-sized and large mammals are essential components of the biodiversity of an area, contributing decisively to ecosystem balance through pollination, seed dispersal, and population control by predation of common species (Sánchez-Cordero et al. 2014). Mediumsized and large mammals are a charismatic group defined as any mammal whose weight is more than $500 \mathrm{~g}$ (Hoffmann et al. 2010). Mammals have been studied with a wide variety of techniques, and the most commonly used ones in biodiversity studies are camera-trapping, active search for tracks, traces and scats, capture and recapture, olfactory stations, and radiotelemetry (Arévalo 2001). These techniques allow for the collection of ecological data on difficult-to-observe species such as carnivores but also allow for the documentation of diversity in different ecosystems, allowing wildlife managers to generate conservation and management plans (Trolliet et al. 2014).

Mexico is recognized as a megadiverse country, with 496 species of land mammals recorded (Ramírez-Pulido et al. 2014). Chihuahua is the largest state in Mexico with 
an area of 247,460 $\mathrm{km}^{2}$ (INEGI 2005), where 133 species of mammals have been identified from four large ecological regions: quebradas, sierra, valleys, and arid lands (Lopéz-González and García-Mendoza 2012). According to López-González and García-Mendoza (2012), 32 species of medium-sized and large mammals have been recorded in Chihuahua, which represents approximately a quarter of the 133 mammals known to occur in the state.

Recent studies on wild mammals of Chihuahua are scarce. Only a few works have been published, and most have been carried out in the Reserva de la Biosfera de Janos, an area characterized by scrub and grassland vegetation. There, studies have recorded the diversity of mammals (Pacheco et al. 2000) as well as the diversity and prevalence of parasites associated with mammals (Fernandez-Gonzalez et al. 2016; Lopez-Perez et al. 2017, 2018, 2019).

Other studies on parasites of mammals have been carried out in Rancho Experimental Teseachi, our study area; Álvarez-Córdova et al. (2019) found a new record of a parasite in Coyotes, Canis latrans (Say, 1823), and Hernández-Urbina et al. (2020) also studied parasites of Coyotes in the Área de Protección de Flora y Fauna Medanos de Samalayuca. However, only a few surveys have been recently made in the mountainous areas of Chihuahua (Sánchez-Mateo et al. 2007; Medina-Torres et al. 2015; Pérez-Amezola et al. 2020).

The Rancho Experimental Teseachi is owned by the Facultad de Zootecnia y Ecología de la Universidad Autónoma de Chihuahua, and the main goal of the ranch is teaching and research in animal science and natural resources. Because of agriculture and livestock ranching, the natural vegetation in parts of the ranch land has been modified, but no study has documented the local mammal fauna. The objective of our study was to survey the medium-sized and large mammals in the study area using different sampling techniques. The availability of a checklist of medium-sized and large mammals will give local authorities and Rancho Experimental Teseachi managers, researchers, and students knowledge of which species of mammals occur at the ranch. This information will help to improve the conservation and management of the natural resources in the area.

\section{Study Area}

Our study was carried out at Rancho Experimental Teseachi (at approximate center, $28^{\circ} 53^{\prime} 44^{\prime \prime} \mathrm{N}, 107^{\circ} 27^{\prime} 22^{\prime \prime} \mathrm{W}$, 2,250 $\mathrm{m}$ a.s.1.), which has an approximate area of 12,300 ha. The ranch is $210 \mathrm{~km}$ northwest of the city of Chihuahua, which is the capital of the state of Chihuahua (Fig. 1). The Rancho Experimental Teseachi is encompassed within the municipalities of Bachiniva, Namiquipa, and Guerrero (Álvarez-Córdova et al. 2019). The landscape is characterized by having low hills and high mountain ranges displaying a mixture of open grasslands, oak chaparral, pine-oak forest, and temperate forest (COTECOCA 1978; Álvarez-Córdova et al. 2019). We surveyed in pine-oak forest and open grassland habitats.

The open grassland habitat is distributed from the central part of the state of Chihuahua to the state of Durango, between 1,800 and $2,000 \mathrm{~m}$ a.s.l. It is formed by meadows of medium-height $(0.50-1.00 \mathrm{~m})$ and perennial grasses and regularly lacks shrubs and trees. The species that characterize this habitat are mainly Bouteloa gracilis (Willd. ex Kunth) Lag. ex Griffiths and Bouteloa hirsuta Lag. The topography consists of undulating, expansive plains and low, rounded hills with slopes up to $15 \%$. The pine-oak forest is formed by the association of two groups of tree species: medium-sized $(6-10 \mathrm{~m})$ trees belonging to the genus Pinus L. and smaller (4 to 6 m) trees of the genus Quercus L. This habitat is located on the middle slopes of the Sierra Madre Occidental and covers a large part of the western parts of Chihuahua, including Namiquipa, between 1,000 and 2,400 m a.s.1. The topography of this terrain is steep slopes and ravines (COTECOCA 1978).

\section{Methods}

Data collection and identification of mammals. To increase the probability of recording most of the medium-sized and large mammal species that occur in the ranch, the sampling effort was equal in both habitats, and three monitoring techniques were used. We used fixed scent stations (SS) to record tracks. Ten SS were set up in each type of habitat. SS were $1 \mathrm{~m}$ in diameter and baited with chicken and sardine. Each SS was separated by $500 \mathrm{~m}$ in series from the next SS, and these $\mathrm{SS}$ extended the length of a $5 \mathrm{~km}$ transect in open grassland and pine-oak forest. We set eight camera traps (CT; Moultrie A-30 Game Camera) randomly in different sites, and each CT was separated from its nearest CT by $500 \mathrm{~m}$. These CT were placed at an average height of $45 \mathrm{~cm}$ above the ground. We searched for and collected tracks (T) (Arévalo 2001). Fieldwork was carried out from April 2018 to March 2019, totaling 12 sampling visits. Each SS was activated during the afternoon and checked the next day (two nights/month). The CT were left active full time for three days, and the tracks were searched and collected at the time of setting the scent stations and checking the camera traps. Mammals recorded by the three techniques were identified to species following Aranda (2000). Once the records were obtained, a database was created and species accumulation curve as well as estimation curves (bootstrap and jackknife) for each habitat sampled were plotted and $\alpha$ and $\beta$ diversity indexes were calculated with EstimateS v. 9.10 (Colwell 2004). The curves were created to evaluate the sampling effort in each habitat and to determine if additional species could yet be recorded in the area (Colwell 2004). 


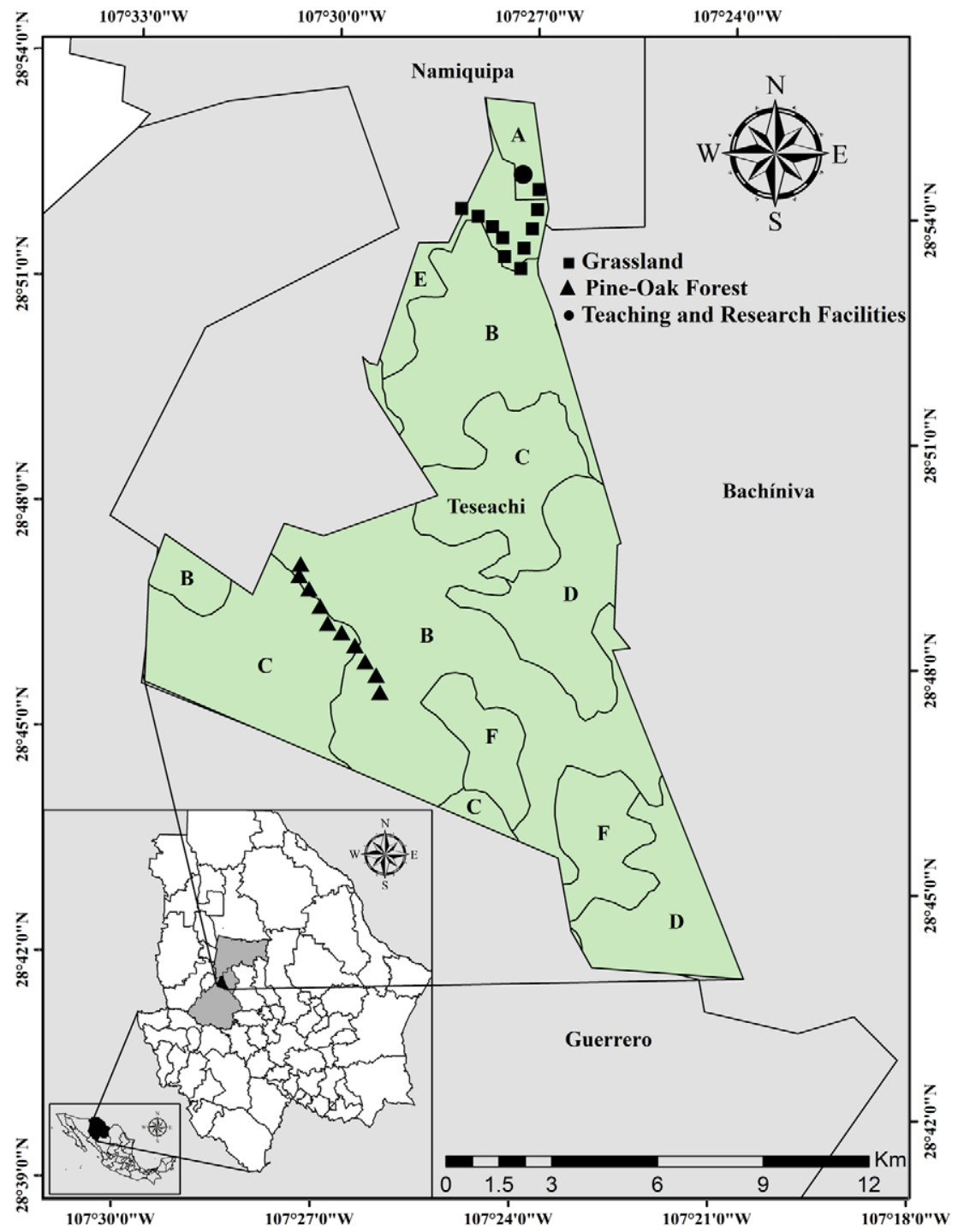

Figure 1. Geographic location of the Rancho Experimental Teseachi, Chihuahua, Mexico, sampling points and vegetation types. Squares $=$ grassland; triangles $=$ pine-oak forest. $\mathrm{A}=$ agriculture fields, $\mathrm{B}=$ oak forest, $\mathrm{C}=$ oak-pine forest, $\mathrm{D}=$ pine-oak forest, $\mathrm{E}=\mathrm{Grassland}, \mathrm{F}=$ secondary vegetation.

\section{Results}

A total of 16 species of medium-sized and large mammals were recorded considering the two habitats for the Rancho Experimental Teseachi (Table 1). None of these species are endemic to Mexico, globally threatened (IUCN 2019), or on the Official Mexican List of threatened taxa (Norma Oficial Mexicana 059; Semarnat 2010). The habitat with the highest species diversity was the pine-oak forest (POF) with all 16 species recorded ( $\alpha=16$, Margalef index 3.21; Table 1, Figs. 2, 3). In the open grassland (OMG) habitat, only nine species were recorded: Canis latrans, Urocyon cinereoargenteus (Schreber, 1775), Lynx rufus (Schreber, 1777), Odocoileus virginianus (Zimmermann, 1780), Conepatus leuconotus (Lichtenstein, 1832), Sylvilagus cf. floridanus (J.A. Allen, 1890), Lepus californicus (Gray, 1837), Otospermophilus cf. variegatus (Erxleben, 1777) and Dicotyles tajacu (Linnaeus, 1758) ( $\alpha=9$, Margalef index 1.67;
Table 1, Figs. 2, 3). Total diversity between both ecosystems was $\beta=7$.

The species with the highest number of records in our study was $C$. latrans $(n=109)$, followed by $U$. cinereoargenteus $(n=80)$ and D. tajacu $(n=16)$. On the other hand, species such as Nasua narica (Linnaeus, 1766), Procyon lotor (Linnaeus, 1758), Ursus americanus (Pallas, 1780) and Spilogale gracilis (Merriam, 1890), were recorded only once (Fig. 4). The species accumulation curve tended towards an asymptote for OMG; however, the opposite was observed for POF, where the curve tended to increase, suggesting that other species may still be recorded in this type of habitat (Fig. 5).

Annotated list. All records were obtained using noninvasive methods, except one of the two records of Procyon lotor, which is based on a skull from a road-killed animal reported by Gómez-Valenzuela et al. (2017). All records lack sex and age information because all data were compiled from camera traps or tracks; all photographs are deposited at the Colección de Fotografías 
Table 1. Taxonomic list of the medium-sized and large mammals recorded at Rancho Experimental Teseachi, Chihuahua, Mexico. Taxonomic arrangement follows taxonomic proposal by Ramírez-Pulido et al. (2014). Record method: Scent station = SS, Camera trap = CT, Tracks $=$ T, No protection $=$ NP, Least Concern $=$ LC, No endemic $=$ NE. Conservation status according to the NOM-ECOL 059-2010 (SEMARNAT 2010) and to the Red list of threatened species of the International Union for Conservation of Nature (IUCN 2015), Endemism was defined following Ceballos et al. (2005). Ecological regions classification follows López-González and García-Mendoza (2014): quebradas $=\mathrm{Q}$, sierra $=\mathrm{S}$, valleys $=\mathrm{V}$, arid $=\mathrm{A}$.

\begin{tabular}{|c|c|c|c|c|c|}
\hline Taxa & Record method & NOM-059 & IUCN & Endemism & Ecological regions \\
\hline \multicolumn{6}{|l|}{ Order Lagomorpha } \\
\hline \multicolumn{6}{|l|}{ Family Leporidae } \\
\hline $\begin{array}{l}\text { Black-tailed Jackrabbit } \\
\text { Lepus californicus Gray, } 1837\end{array}$ & SS, T & NP & LC & NE & $S, V, A$ \\
\hline $\begin{array}{l}\text { Eastern Cottontail Rabbit } \\
\text { Sylvilagus cf. floridanus (Allen, 1890) }\end{array}$ & SS, CT & NP & $\mathrm{LC}$ & $\mathrm{NE}$ & $S, V, A$ \\
\hline \multicolumn{6}{|l|}{ Order Rodentia } \\
\hline \multicolumn{6}{|l|}{ Family Sciuridae } \\
\hline $\begin{array}{l}\text { Rock Squirrel } \\
\text { Otospermophilus cf. variegatus (Erxleben, 1777) }\end{array}$ & SS, CT & NP & $\mathrm{LC}$ & $\mathrm{NE}$ & $Q, S, V, A$ \\
\hline \multicolumn{6}{|l|}{ Order Carnivora } \\
\hline \multicolumn{6}{|l|}{ Family Felidae } \\
\hline $\begin{array}{l}\text { Bobcat } \\
\text { Lynx rufus (Schreber, 1777) }\end{array}$ & $\mathrm{SS}, \mathrm{CT}, \mathrm{T}$ & NP & LC & NE & $Q, S, V$ \\
\hline \multicolumn{5}{|l|}{ Cougar } & $S, V, A$ \\
\hline \multicolumn{6}{|l|}{ Family Canidae } \\
\hline \multicolumn{6}{|l|}{ Coyote } \\
\hline Canis latrans Say, 1823 & $\mathrm{SS}, \mathrm{CT}, \mathrm{T}$ & NP & LC & NE & $S, V, A$ \\
\hline \multicolumn{6}{|l|}{ Gray Fox } \\
\hline \multicolumn{6}{|l|}{ Family Ursidae } \\
\hline $\begin{array}{l}\text { Black Bear } \\
\text { Ursus americanus (Pallas, 1780) }\end{array}$ & $\mathrm{T}$ & NP & $\mathrm{LC}$ & $\mathrm{NE}$ & $S, V$ \\
\hline \multicolumn{6}{|l|}{ Order Carnivora } \\
\hline \multicolumn{6}{|l|}{ Family Mephitidae } \\
\hline \multicolumn{6}{|l|}{ American Hog-nosed Skunk } \\
\hline \multicolumn{6}{|l|}{ Hooded Skunk } \\
\hline Mephitis macroura Lichtenstein, 1832 & $\mathrm{SS}, \mathrm{CT}, \mathrm{T}$ & NP & $\mathrm{LC}$ & $\mathrm{NE}$ & $Q, S, V, A$ \\
\hline \multicolumn{6}{|l|}{ Striped Skunk } \\
\hline \multicolumn{5}{|l|}{ Western Spotted Skunk } & $Q, S, A$ \\
\hline \multicolumn{6}{|l|}{ Family Procyonidae } \\
\hline \multicolumn{5}{|l|}{ White-nosed Coati } & $0, S$ \\
\hline \multicolumn{5}{|l|}{ Raccoon } & $Q, S, V$ \\
\hline \multicolumn{6}{|l|}{ Order Artiodactyla } \\
\hline \multicolumn{6}{|l|}{ Family Tayassuidae } \\
\hline $\begin{array}{l}\text { Collared Peccari } \\
\text { Dicotyles tajacu (Linnaeus, 1758) }\end{array}$ & $\mathrm{SS}, \mathrm{CT}, \mathrm{T}$ & NP & LC & NE & $0, S$ \\
\hline $\begin{array}{l}\text { White-tailed Deer } \\
\text { Odocoileus virginianus (Zimmermann, 1780) }\end{array}$ & $\mathrm{SS}, \mathrm{CT}, \mathrm{T}$ & NP & $\mathrm{LC}$ & $\mathrm{NE}$ & $Q, S, V, A$ \\
\hline
\end{tabular}

(UACH-CF) of the Facultad de Zootecnia y Ecología, Universidad Autónoma de Chihuahua; track records do not have a collection number.

Order Lagomorpha

Family Leporidae

\section{Lepus californicus (Gray, 1837)}

Black-tailed Jackrabbit

Figure 2A

Material examined. MEXICO - Chihuahua - 4; Municipality of Namiquipa; $28^{\circ} 46^{\prime} 42^{\prime \prime} \mathrm{N}, 107^{\circ} 27^{\prime} 45^{\prime \prime} \mathrm{W}$; elevation 2,170 m a.s.l.; 21 April 2018; obs. F. Álvarez-Córdova 4 ; Municipality of Namiquipa; $28^{\circ} 47^{\prime} 01^{\prime \prime} \mathrm{N}, 107^{\circ}$ $28^{\prime} 12^{\prime \prime} \mathrm{W}$; elevation 2,138 m a.s.1.; 2 October 2020; obs. F. Álvarez-Córdova • 2; 28 $8^{\circ} 47^{\prime} 18^{\prime \prime} \mathrm{N}, 107^{\circ} 28^{\prime} 36^{\prime \prime} \mathrm{W}$; elevation 2,121 m a.s.1.; 6 October 2018; obs. F. ÁlvarezCórdova • 1; Municipality of Namiquipa; $28^{\circ} 47^{\prime} 30^{\prime \prime} \mathrm{N}$, $107^{\circ} 28^{\prime} 49^{\prime \prime} \mathrm{W}$, elevation 2,124 m a.s.1.; 21 January 2021; obs. F. Álvarez-Córdova.

Identification. This is the second largest species of the genus in Chihuahua and the only species inhabiting the highlands of the Sierra Madre Occidental. Its large, blacktipped ears and hind feet make it distinguishable from $S$. 


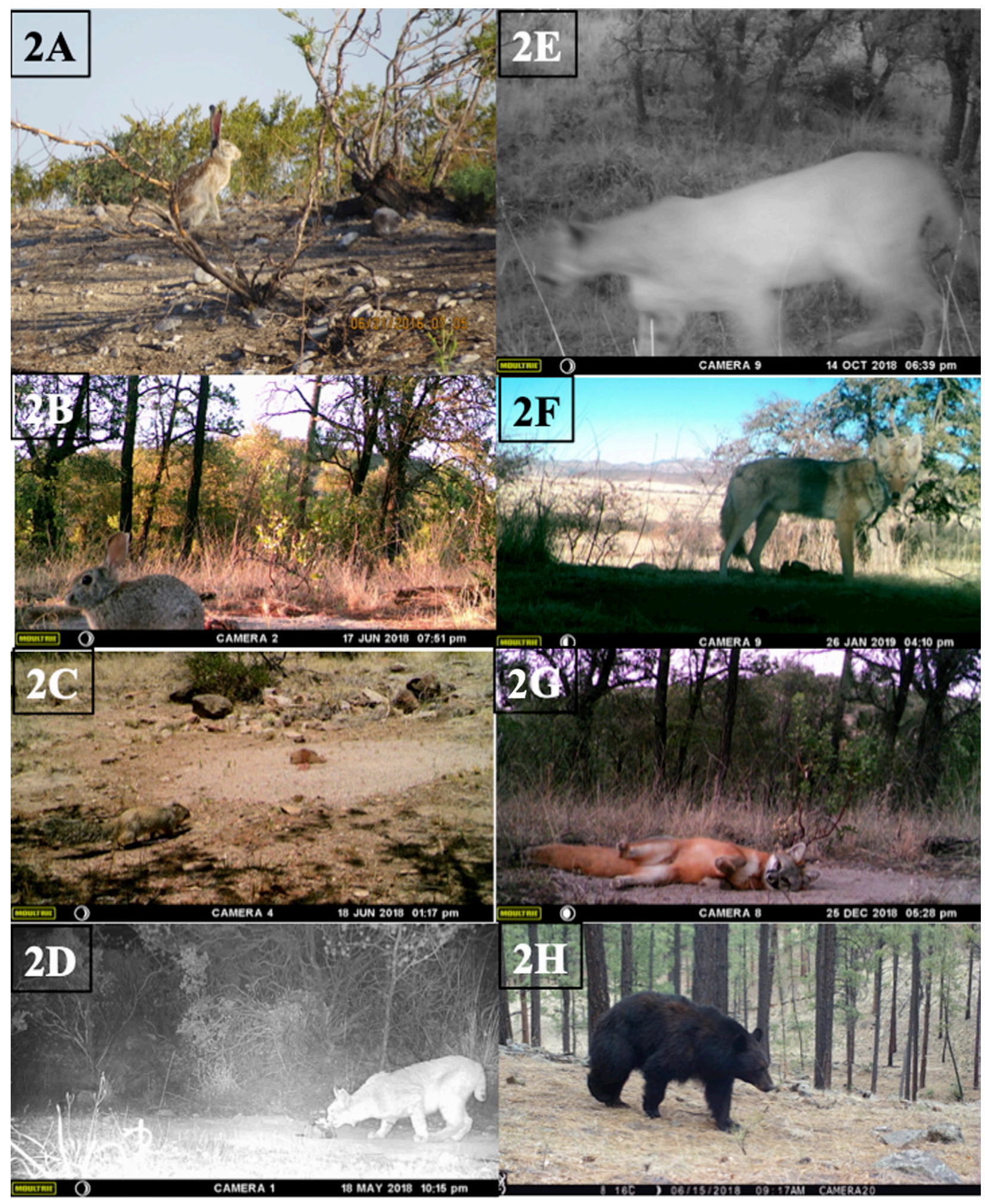

Figure 2. Species of medium-sized and large mammals detected at the Rancho Experimental Teseachi, Namiquipa, Chihuahua, Mexico. A. Lepus californicus, Black-tailed Jackrabbit. B. Sylvilagus floridanus, Eastern Cottontail. C. Otospermophilus variegatus, Rock Squirrel. D. Lynx rufus, Bobcat. E. Puma concolor, Cougar. F. Canis latrans, Coyote. G. Urocyon cinereoargenteus, Gray Fox. H. Ursus americanus, Black bear (Image from Gila, New Mexico, USA, provided by A. González - PAPIIT-IN212217-UNAM).

floridanus in the area. There is a black line in the middle of the back that reaches the tail. The sides are light brown mixed with gray hairs (Anderson 1972; Best 1996).

Distribution. Central and western United States of America (USA); in Mexico, in Baja California, the Sonoran and Chihuahuan deserts to Tamaulipas in eastern
Mexico, through the Mexican Plateau to northern Tlaxcala in the Transmexican Volcanic Belt (TMVB) in central Mexico (Best 1996). Recorded habitats in Chihuahua are sierras, valleys, and arid lands.

Remarks. This is the only species of Lepus Linnaeus, 1758 in the region (López-González and García-Mendoza 


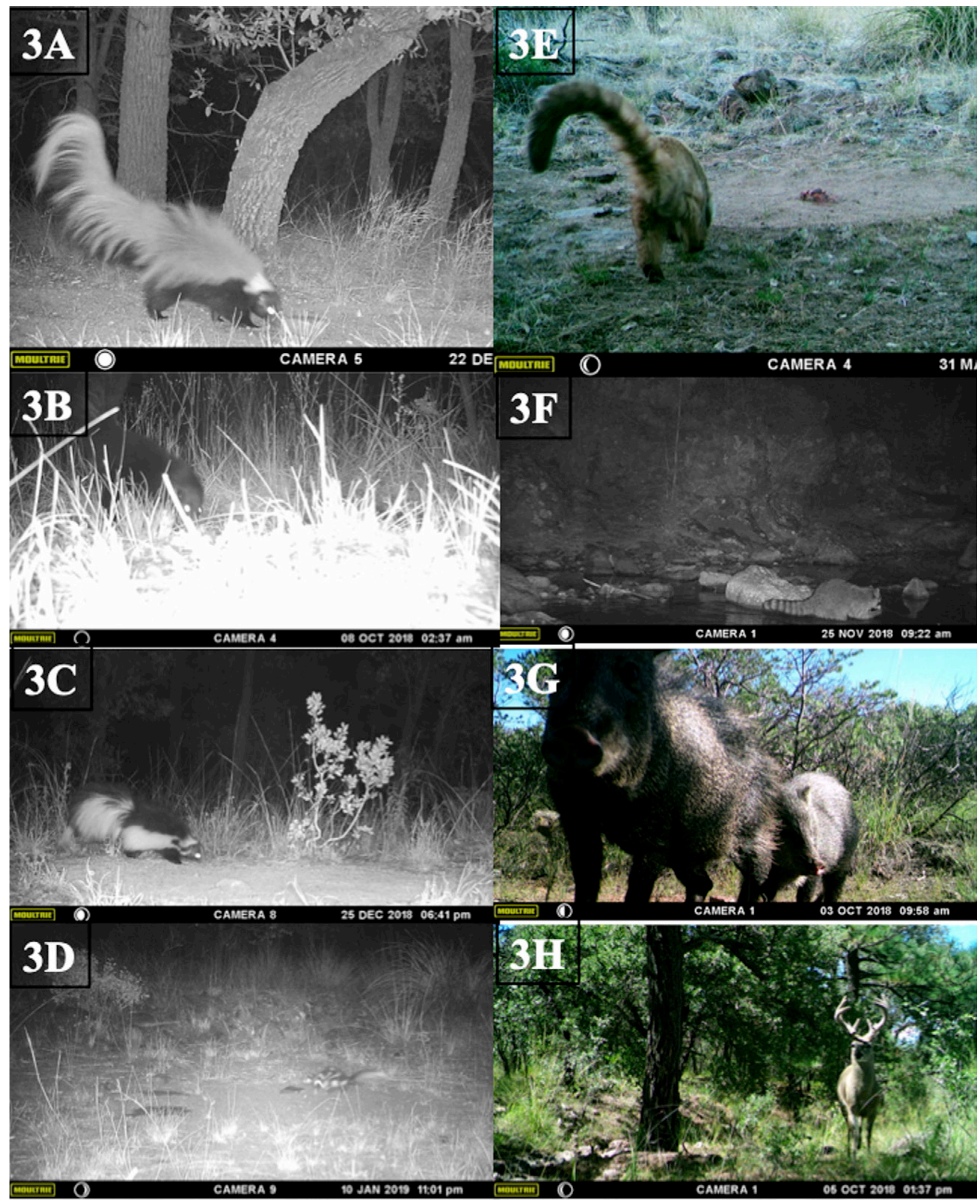

Figure 3. Species of medium-sized and large mammals detected at the Rancho Experimental Teseachi, Namiquipa, Chihuahua, Mexico. A. Conepatus leuconotus, Hog-nosed Skunk. B. Mephitis macroura, Hooded Skunk. C. Mephitis mephitis, Stripped Skunk. D. Spilogale gracilis, Western Spotted Skunk. E. Nasua nasua, White-nosed Coati. F. Procyon lotor, Raccon. G. Dicotyles tajacu, Collared Peccary. H. Odocoileus virginianus, White-tailed Deer.

2012). Lepus californicus is frequently seen at night in the open areas of the ranch.

\section{Sylvilagus floridanus (Allen, 1890)}

Eastern Cottontail Rabbit

Figure 2B
Material examined. Mexico - Chihuahua - 23; Municipality of Namiquipa; $28^{\circ} 46^{\prime} 32^{\prime \prime} \mathrm{N}, 107^{\circ} 27^{\prime} 33^{\prime \prime} \mathrm{W}$; elevation 2,191 m a.s.1.; May, June, November 2018; obs. F. Álvarez-Córdova - 62 - Municipality of Namiquipa; $28^{\circ} 46^{\prime} 42^{\prime \prime} \mathrm{N}, 107^{\circ} 27^{\prime} 45^{\prime \prime} \mathrm{W}$; elevation 2,170 m a.s.l.; May, June, August, October 2018, January, March 2019; 


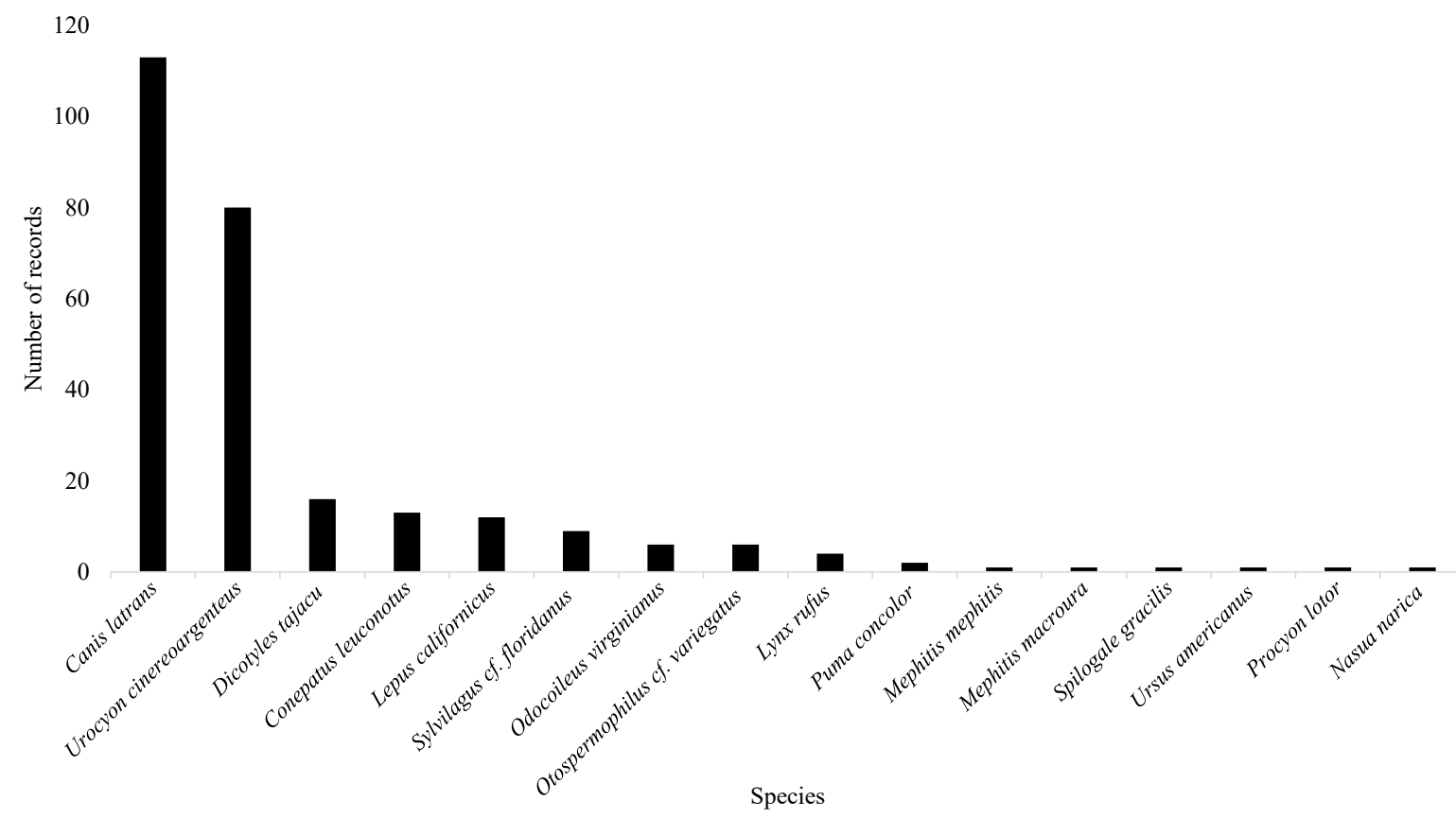

Figure 4. Number of records for medium-sized and large mammals at Rancho Experimental Teseachi, Chihuahua, Mexico.

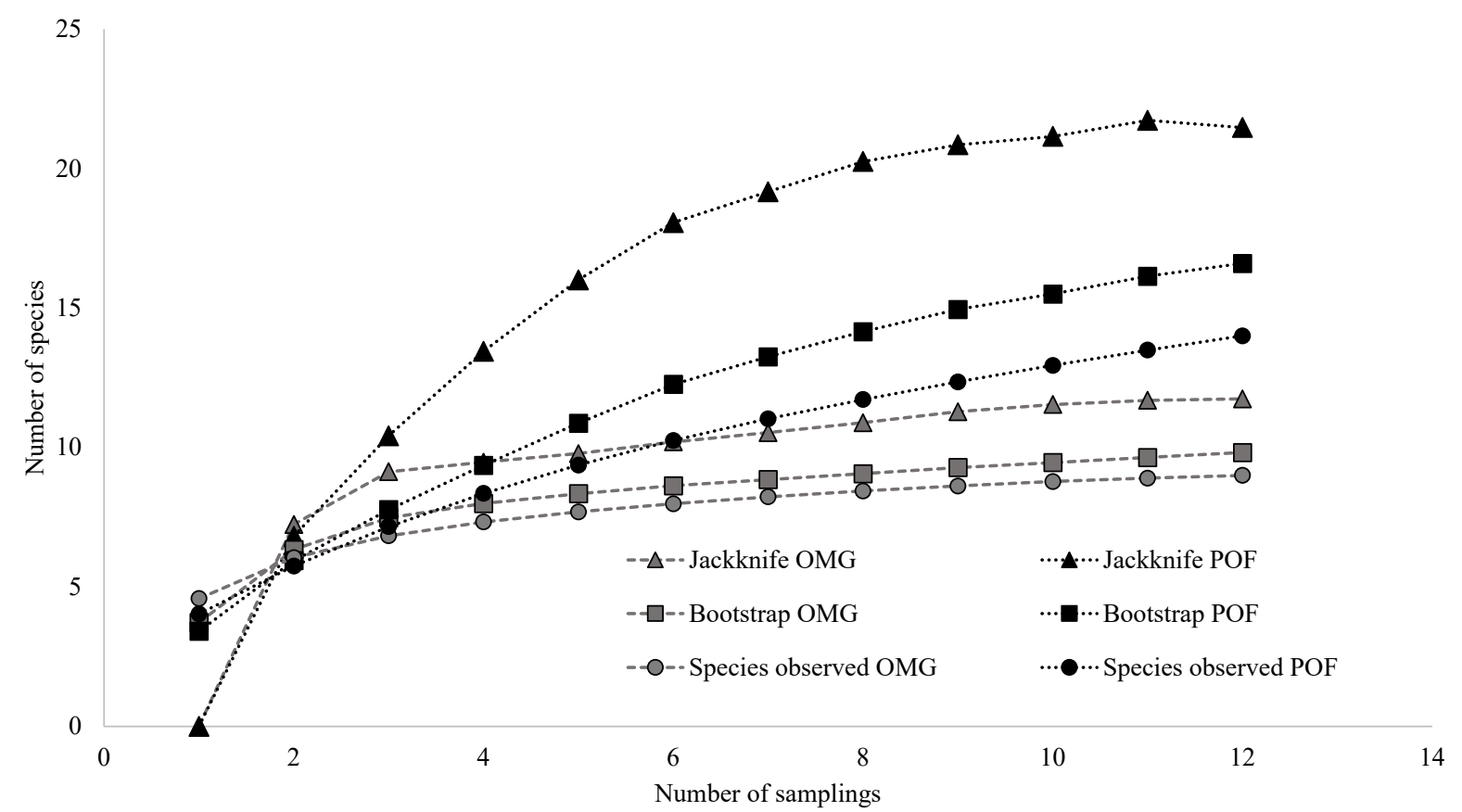

Figure 5. Species accumulation curves for open grassland (OMG) vs. pine-oak forest (POF) for medium and large mammals at Rancho Experimental Teseachi, Chihuahua, Mexico through 12 sampling visits.

obs. F. Álvarez-Córdova • 9; Municipality of Namiquipa; $28^{\circ} 47^{\prime} 01^{\prime \prime} \mathrm{N}, 107^{\circ} 28^{\prime} 12^{\prime \prime} \mathrm{W}$; elevation $2,138 \mathrm{~m}$ a.s.l.; October 2018, January 2019; obs. F. Álvarez-Córdova - 79; Municipality of Namiquipa; $28^{\circ} 47^{\prime} 18^{\prime \prime} \mathrm{N}$, $107^{\circ} 28^{\prime} 36^{\prime \prime} \mathrm{W}$; elevation 2,121 m a.s.l.; May, June, August, October 2018, January, March 2019; obs. F. Álvarez-Córdova - 2; Municipality of Namiquipa; $28^{\circ} 47^{\prime} 30^{\prime \prime} \mathrm{N}, 107^{\circ} 28^{\prime} 49^{\prime \prime} \mathrm{W}$; elevation. 2,124 m a.s.l.; March 2019; obs. F. Álvarez-Córdova • 19; Municipality of Namiquipa; $28^{\circ} 27^{\prime} 39^{\prime \prime} \mathrm{N}, 107^{\circ} 29^{\prime} 01^{\prime \prime} \mathrm{W}$; elevation 2,110 m a.s.l.; May, June, November 2018, January,
March 2019; obs. F. Álvarez-Córdova • 51; Municipality of Namiquipa; $28^{\circ} 47^{\prime} 49^{\prime \prime} \mathrm{N}, 107^{\circ} 29^{\prime} 02^{\prime \prime} \mathrm{W}$; elevation 2,107 m a.s.l.; May, June, October, November 2018, January 2019; obs. F. Álvarez-Córdova • 13; Municipality of Namiquipa; $28^{\circ} 52^{\prime} 49^{\prime \prime} \mathrm{N}, 107^{\circ} 27^{\prime} 08^{\prime \prime} \mathrm{W}$; elevation 1,876 m a.s.l.; May 2018, January, March 2019; obs. F. Álvarez-Córdova; UACH-CF-5609-5872.

Identification. This is the largest species of Sylvilagus Gray, 1867 in Chihuahua and the only one occurring in the highlands of the Sierra Madre Occidental. It is a large, heavy-bodied rabbit, with a gray-brown coat, and a 
conspicuous white tail. The belly hair is white (Chapman et al. 1980; Lee et al. 2010).

Distribution. From southern Canada, through central, eastern USA and the Mexican highlands (pine, pine-oak forests) to Central America and northern South America (Venezuela and Colombia; Chapman et al. 1980). Recorded habitats in Chihuahua are sierras, valleys, and arid lands.

Remarks. Two species of Sylvilagus have been recorded in Chihuahua (López-González and García-Mendoza 2012): The Eastern Cottontail Rabbit and the Desert Cottontail Rabbit (Sylvilagus audubonii (Baird, 1858)); the former inhabits forested areas (pine and pine-oak forests), and the latter inhabits grassland and desert areas.

Order Rodentia

Family Sciuridae

Otospermophilus variegatus (Erxleben, 1777)

Rock Squirrel

Figure 2C

Material examined. MEXICO - Chihuahua • 8; Municipality of Namiquipa; $28^{\circ} 46^{\prime} 42^{\prime \prime} \mathrm{N}, 107^{\circ} 27^{\prime} 45^{\prime \prime} \mathrm{W}$; elevation 2,170 m a.s.l.; 18 June 2018; obs. F. Álvarez-Córdova - 27; Municipality of Namiquipa; $28^{\circ} 47^{\prime} 18^{\prime \prime} \mathrm{N}, 107^{\circ} 28^{\prime}$ $36^{\prime \prime} \mathrm{W}$; elevation 2,121 m a.s.1.; 24 July 2018; obs. F. Álvarez-Córdova - 119; Municipality of Namiquipa; $28^{\circ} 47^{\prime} 49^{\prime \prime} \mathrm{N}, 107^{\circ} 29^{\prime} 02^{\prime \prime} \mathrm{W}$; elevation 2,107 m a.s.l.; 1, 6, 10-12, 14 October 2018; obs. F. Álvarez-Córdova • 74; $28^{\circ} 52^{\prime} 49^{\prime \prime} \mathrm{N}, 107^{\circ} 27^{\prime} 08^{\prime \prime} \mathrm{W}$; elevation 1,876 m a.s.l.; 12, 18 August 2018, 28 October 2018; obs. F. Álvarez-Córdova; UACH-CF-5873-6100.

Identification. This is the only species of Otospermophilus Brandt, 1844 known for Chihuahua. Otospermophilus variegatus is a medium-sized squirrel, with a mottled, grayish-brown coat and a well-marked, lightcolored ring around each eye. This species has a long, hairy tail (Oaks et al. 1987; Phuong et al. 2014).

Distribution. Central, southwestern USA, through most of northern and central Mexico to the TMVB (Oaks et al. 1987). Recorded habitats in Chihuahua are quebradas, sierras, valleys, and arid lands.

Remarks. Ten sciurids have been recorded in Chihuahua (López-González and García-Mendoza 2012). Of these, six species are present in the Sierra Madre Occidental. Otospermophilus variegatus is frequently seen in rocky habitats.

Order Carnivora

Family Felidae

\section{Lynx rufus (Schreber, 1777)}

Bobcat

Figure 2D

Material examined. MEXICO - Chihuahua • 6; Municipality of Namiquipa; $28^{\circ} 46^{\prime} 32^{\prime \prime} \mathrm{N}, 107^{\circ} 27^{\prime} 33^{\prime \prime} \mathrm{W}$; elevation 2,191 m a.s.1.; 18 May 2018; obs. F. Álvarez-Córdova • 3; Municipality of Namiquipa; $28^{\circ} 47^{\prime} 01^{\prime \prime} \mathrm{N}, 107^{\circ} 28^{\prime} 12^{\prime \prime} \mathrm{W}$; elevation 2,138 m a.s.1.; 26 October 2019; obs. F. ÁlvarezCórdova - 8; Municipality of Namiquipa; 28 $47^{\prime} 18^{\prime \prime} \mathrm{N}$, $107^{\circ} 28^{\prime} 36^{\prime \prime} \mathrm{W}$; elevation 2,121 m a.s.1.; 26 January 2019; obs. F. Álvarez-Córdova; UACH-CF-6101-6118.

Identification. This is the only species of the genus in Mexico. It is a medium-sized cat, with a short tail and red or grayish dorsal pelage. The underparts are white with black spots. Ears have pointed tufts, and the hair on sides of head are long (Larivière and Walton 1997; Loveless et al. 2016).

Distribution. Southern Canada, USA, through most of northern and central Mexico to the TMVB (Larivière and Walton 1997). Recorded habitats in Chihuahua are quebradas, sierras, and valleys.

Remarks. This species is a common felid inhabiting most of the state (López-González and García-Mendoza 2012), even in urban and semi-urban areas. However, it is rarely observed in the sierras because of its habits.

\section{Puma concolor (Linnaeus, 1771)}

Cougar, Mountain Lion

Figure 2E

Material examined. MEXICO - Chihuahua • 1; Municipality of Namiquipa; $28^{\circ} 47^{\prime} 18^{\prime \prime} \mathrm{N}, 107^{\circ} 28^{\prime} 36^{\prime \prime} \mathrm{W}$; elevation 2,121 m a.s.1.; 14 October 2019; obs. F. Álvarez-Córdova; UACH-CF-6119.

Identification. This is a large cat with a long tail and no spots. The head and ears are small and rounded. The dorsal color is reddish brown, and the underparts are whitish (Currier 1983).

Distribution. Central, southwestern Canada; central, northwest USA, through most of Mexico to southern South America (Currier 1983). Recorded habitats in Chihuahua are quebradas, sierras, and valleys.

Remarks. Puma is the second largest felid in Mexico, second only to Jaguar, Panthera onca (Linnaeus, 1758). Based on current records for Chihuahua (LópezGonzález and García-Mendoza 2012), both species are not sympatric because Jaguar records are restricted to the quebradas.

Family Canidae

Canis latrans (Say, 1823)

Coyote

Figure $2 \mathrm{~F}$

Material examined. MEXICO - Chihuahua - 15; Municipality of Namiquipa; $28^{\circ} 46^{\prime} 32^{\prime \prime} \mathrm{N}, 107^{\circ} 27^{\prime} 33^{\prime \prime} \mathrm{W}$; elevation 2,191 m a.s.1.; 21 April, 20 May 2018; obs. F. Álvarez-Córdova - 41; Municipality of Namiquipa; $28^{\circ} 46^{\prime} 42^{\prime \prime} \mathrm{N}, 107^{\circ} 27^{\prime} 45^{\prime \prime} \mathrm{W}$; elevation 2,170 m a.s.1.; 21 April, 11 October, 12 December 2018; 26 January, 28 October 2019; obs. F. Álvarez-Córdova • 88; Municipality of Namiquipa; $28^{\circ} 47^{\prime} 01^{\prime \prime} \mathrm{N}, 107^{\circ} 28^{\prime} 12^{\prime \prime} \mathrm{W}$; elevation 2,138 m a.s.1.; 5 October, 12, 21 December 2018, 26 January 2019; obs. F. Álvarez-Córdova • 48; Municipality of Namiquipa; $28^{\circ} 47^{\prime} 18^{\prime \prime} \mathrm{N}, 107^{\circ} 28^{\prime} 36^{\prime \prime} \mathrm{W}$; elevation 2,121 
m a.s.l.; 21 April, 5 October, 12, 21 December 2018, 26 January, 28 October 2019; obs. F. Álvarez-Córdova • 2; Municipality of Namiquipa; 28 $47^{\prime} 30^{\prime \prime} \mathrm{N}, 107^{\circ} 28^{\prime} 49^{\prime \prime} \mathrm{W}$; elevation 2,124 m a.s.l.; 11 October 2018; obs. F. ÁlvarezCórdova • 2; Municipality of Namiquipa; $28^{\circ} 27^{\prime} 39^{\prime \prime} \mathrm{N}$, $107^{\circ} 29^{\prime} 01^{\prime \prime} \mathrm{W}$; elevation 2,110 m a.s.1.; 21 December 2018; obs. F. Álvarez-Córdova • 10; Municipality of Namiquipa; $28^{\circ} 47^{\prime} 49^{\prime \prime} \mathrm{N}, 107^{\circ} 29^{\prime} 02^{\prime \prime} \mathrm{W}$; elevation 2,107 m a.s.1.; 13 October 2018, 18 January 2019; obs. F. Álvarez-Córdova; UACH-CF-6120-6325.

Identification. Canis latrans is the only species of the genus occurring in the study area. It has a dog-like body, the color of the pelage ranges from gray-brown to yellowbrown on the dorsum, and there is whitish fur ventrally. It has a long, narrow snout, the ears are triangular on top of the head, and the tail is long and bushy (Bekoff 1977).

Distribution. Canada, USA, and Mexico to Panama (Bekoff 1977). Recorded habitats in Chihuahua are sierras, valleys, and arid lands.

Remarks. Two members of the genus Canis Linnaeus, 1758 (C. latrans and Gray Wolf, C. lupus Linnaeus, 1758) were sympatric in some parts of Chihuahua. However, $C$. lupus was extirpated in the state, possibly allowing for Coyote to expand its distribution.

\section{Urocyon cinereoargenteus (Schreber, 1775) Gray Fox}

Figure 2G

Material examined. MEXICO - Chihuahua - 224; $\mathrm{Mu}-$ nicipality of Namiquipa; $28^{\circ} 46^{\prime} 32^{\prime \prime} \mathrm{N}, 107^{\circ} 27^{\prime} 33^{\prime \prime} \mathrm{W}$; elevation 2,191 m a.s.1.; 18 May, 17 June, 18-19 August; 25 January, 10 December 2019; obs. F. Álvarez-Córdova • 417; Municipality of Namiquipa; $28^{\circ} 46^{\prime} 42^{\prime \prime} \mathrm{N}, 107^{\circ} 27^{\prime} 45^{\prime \prime} \mathrm{W}$; elevation 2,170 m a.s.1.; 18 May, 17 June, 18-19 August, 29 September 2019; 25 January, 19 October, 10 December 2019; obs. F. Álvarez-Córdova - 37; Municipality of Namiquipa; $28^{\circ} 47^{\prime} 01^{\prime \prime} \mathrm{N}, 107^{\circ} 28^{\prime} 12^{\prime \prime} \mathrm{W}$; elevation 2,138 m a.s.1.; 8, 16 October, 15 November 2019; obs. F. ÁlvarezCórdova • 188; Municipality of Namiquipa; 28 47'18"N, $107^{\circ} 28^{\prime} 36^{\prime \prime} \mathrm{W}$; elevation 2,121 m a.s.l.; 18 May, 17 June, 19 August, 29-30 September 2018; 25 January, 16, 19 October, 10 December 2019; obs. F. Álvarez-Córdova • 69; Municipality of Namiquipa; 28 $47^{\prime} 30^{\prime \prime} \mathrm{N}, 107^{\circ} 28^{\prime} 49^{\prime \prime} \mathrm{W}$; elevation 2,124 m a.s.1.; 29 September 2018; 19 August, 12 October 2019; obs. F. Álvarez-Córdova • 90; Municipality of Namiquipa; $28^{\circ} 27^{\prime} 39^{\prime \prime} \mathrm{N}, 107^{\circ} 29^{\prime} 01^{\prime \prime} \mathrm{W}$; elevation 2,110 m a.s.1.; 18 May 2018; 10 December 2019; obs. F. ÁlvarezCórdova - 253; Municipality of Namiquipa; 28 47'49"N, $107^{\circ} 29^{\prime} 02^{\prime \prime} \mathrm{W}$; elevation 2,107 m a.s.1.; 18 May, 18-19 August, 2018; 25 January, 19 October, 10 December 2019; obs. F. Álvarez-Córdova - 505; Municipality of Namiquipa; 28 52'49'N, 107²7'08'W; elevation 1,876 m a.s.l.; 17 May, 17 June, 18-19 August, 29 September 2018; 25 January, 19 October, 10 December 2019; obs. F. ÁlvarezCórdova; UACH-CF-6326-8108.

Identification. This is the only species of Urocyon Baird, 1857 to occur in Mexico. Urocyon cinereoargenteus is smaller than Coyote, with peppery-gray dorsal pelage and red-brown on the sides, chest, and the back of head. Legs and feet are also orange. It has a long bushy tail and a pointed muzzle and ears (Fritzell and Haroldson 1982). Distribution. Southern Canada, most of the USA, through Mexico to northern South America (Fritzell and Haroldson 1982). Recorded habitats in Chihuahua are quebradas, sierras, valleys, and arid lands.

Remarks. This species is the most widely distributed canid in Chihuahua (López-González and García-Mendoza 2012). It was the most frequently observed medium-sized and large mammal in the Rancho Experimental Teseachi.

Family Ursidae

\section{Ursus americanus (Pallas, 1780) \\ Black Bear}

Figure $2 \mathrm{H}$

Material examined. MEXICO - Chihuahua • 1 Municipality of Namiquipa, Potrero Lajas, $28^{\circ} 46^{\prime} 34^{\prime \prime} \mathrm{N}, 107^{\circ}$ 27'34"W; elevation 2,180 m a.s.l.; 16 Jan. 2018; obs. F. Álvarez-Córdova.

Identification. This is the only extant species of Ursus Linnaeus, 1758 in Mexico. It is a medium-sized bear with long, coarse, black or brown fur (Larivière 2001).

Distribution. Canada, USA, and Mexico through the pine, pine-oak forests of the Sierra Madre Occidental and Sierra Madre Oriental (Larivière 2001). Recorded habitats in Chihuahua are sierras and valleys.

Remarks. This species is now extirpated from most of northern Mexico. It only survives in small patches of forests in the Sierra Madre Occidental and Sierra Madre Oriental in central and northern Mexico (Scheick and McCown 2014). The record presented here is based on a single scat.

Family Mephitidae

Conepatus leuconotus (Lichtenstein, 1832)

Hog-nosed Skunk

Figure 3A

Material examined. $\mathrm{MEXICO}-$ Chihuahua $・ 3$; Municipality of Namiquipa; $28^{\circ} 47^{\prime} 30^{\prime \prime} \mathrm{N}, 107^{\circ} 28^{\prime} 49^{\prime \prime} \mathrm{W}$; elevation 2,124 m a.s.1.; 21 April 2018; obs. F. Álvarez-Córdova • 6; Municipality of Namiquipa; $28^{\circ} 47^{\prime} 49^{\prime \prime} \mathrm{N}, 107^{\circ} 29^{\prime} 02^{\prime \prime} \mathrm{W}$; elevation 2,107 m a.s.1.; 17 June 2018; obs. F. ÁlvarezCórdova - 16; Municipality of Namiquipa; 28 52'49'N, $107^{\circ} 27^{\prime} 08^{\prime \prime} \mathrm{W}$; elevation 1,876 m a.s.l.; 12 October 2019; obs. F. Álvarez-Córdova; UACH-CF-8109-8133.

Identification. This is the largest skunk and only species of Conepatus Gray, 1837 occurring in Chihuahua. The body is black with a white dorsal band and a pig-like nose (Dragoo et al. 2003; Dragoo and Sheffield 2009).

Distribution. Southwestern USA through most of Mexico (but not in Baja California) to northern Nicaragua (Dragoo and Sheffield 2009). Recorded habitats in Chihuahua are sierras and valleys. 
Remarks. Four skunks have been recorded in Chihuahua and in the ranch (López-González and GarcíaMendoza 2012). This species is easily diagnosed by its pig-like nose.

\section{Mephitis macroura (Lichtenstein, 1832) \\ Hooded Skunk \\ Figure 3B}

Material examined. MEXICO - Chihuahua - 3; Municipality of Namiquipa; $28^{\circ} 46^{\prime} 42^{\prime \prime} \mathrm{N}, 107^{\circ} 27^{\prime} 45^{\prime \prime} \mathrm{W}$; elevation 2,170 m a.s.1.; 19 May 2018; obs. F. ÁlvarezCórdova - 9; Municipality of Namiquipa; 28 $47^{\prime} 18^{\prime \prime} \mathrm{N}$, $107^{\circ} 28^{\prime} 36^{\prime \prime} \mathrm{W}$; elevation 2,121 m a.s.1.; 28 September 2019; obs. F. Álvarez-Córdova • 3; Municipality of Namiquipa; $28^{\circ} 47^{\prime} 30^{\prime \prime} \mathrm{N}, 107^{\circ} 28^{\prime} 49^{\prime \prime} \mathrm{W}$; elevation 2,124 m a.s.1.; 8 October 2018; obs. F. Álvarez-Córdova • 6; Municipality of Namiquipa; $28^{\circ} 47^{\prime} 49^{\prime \prime} \mathrm{N}, 107^{\circ} 29^{\prime} 02^{\prime \prime} \mathrm{W}$; elevation 2,107 m a.s.1.; 7-8 October 2019; obs. F. Álvarez-Córdova • 3; Municipality of Namiquipa; $28^{\circ} 52^{\prime} 49^{\prime \prime} \mathrm{N}, 107^{\circ} 27^{\prime} 08^{\prime} \mathrm{W}$; elevation 1,876 m a.s.1.; 8 October 2018; obs. F. ÁlvarezCórdova; UACH-CF-8134-8157.

Identification. This species is very similar to Mephitis mephitis (Schreber, 1766); however, it differs in having a longer and softer fur with hair forming a hood-like structure on the dorsal part of the neck (Hwang and Larivière 2001).

Distribution. Southwestern USA through most of Mexico (but not in Baja California) to northern Nicaragua (Hwang and Larivière 2001). Recorded habitats in Chihuahua are quebradas, sierras, valleys, and arid lands.

Remarks. This is one of the two species of skunk in Chihuahua belonging to the genus Mephitis É. Geoffroy Saint-Hilaire and Cuvier, 1795 (López-González and García-Mendoza 2012). It occurs in every ecological region of the state.

\section{Mephitis mephitis (Schreber, 1776) \\ Striped Skunk \\ Figure 3C}

Material examined. $\mathrm{MEXICO}-$ Chihuahua $・ 3$; Municipality of Namiquipa; $28^{\circ} 46^{\prime} 42^{\prime \prime} \mathrm{N}, 107^{\circ} 27^{\prime} 45^{\prime \prime} \mathrm{W}$; elevation 2,170 m a.s.l.; 13 October 2018; obs. F. Álvarez-Córdova 1 4; Municipality of Namiquipa; $28^{\circ} 47^{\prime} 49^{\prime \prime} \mathrm{N}, 107^{\circ}$ 29'02"W; elevation 2,107 m a.s.1.; 21-22 December 2018; obs. F. Álvarez-Córdova • 11; Municipality of Namiquipa; 28 52'49'N, 107²7'08'W; elevation 1,876 m a.s.l.; 10 January 2019; obs. F. Álvarez-Córdova; UACH-CF-8158-8175.

Identification. Mephitis mephitis can be distinguished from other skunks in the area by the conspicuous white stripe running dorsally from head to tail. The stripe begins as a single white hair spot on the head and divides into two thinner stripes (Wade-Smith and Verts 1982).

Distribution. Canada, most of the USA, and northern Mexico (Wade-Smith and Verts 1982). Recorded habitats in Chihuahua are sierras, valleys and arid.

Remarks. Striped Skunk is widely distributed in the state (López-González and García-Mendoza 2012) and is absent only in quebradas where only Hooded Skunk occurs.

\section{Spilogale gracilis (Merriam, 1890)}

Western Spotted Skunk

Figure 3D

Material examined. MEXICO - Chihuahua - 6; Municipality of Namiquipa; $28^{\circ} 47^{\prime} 18^{\prime \prime} \mathrm{N}, 107^{\circ} 28^{\prime} 36^{\prime \prime} \mathrm{W}$; elevation 2,121 m a.s.1.; 10 January 2019; obs. F. ÁlvarezCórdova; UACH-CF-8176-8181.

Identification. This is the only species of Spilogale Gray, 1865 recorded in Chihuahua. It is black dorsally with extensive white markings and a dorsal pair of white stripes beginning at the ears (Van Gelder 1959; Verts et al. 2001). It is smaller than the two other skunk genera in Chihuahua. Distribution. Southwestern Canada, western USA to Mexico (Baja California through northern Mexico to the TMVB; Verts et al. 2001). Recorded habitats in Chihuahua are quebradas, sierras and arid lands.

Remarks. This is the smallest of the skunks in Chihuahua (López-González and García-Mendoza 2012). It has been recorded in three of the four ecological regions of the state; however, in the ranch, it is the skunk with the fewest records.

Family Procyonidae

Nasua narica (Linnaeus, 1766)

White-nosed Coati

Figure 3E

Material examined. MEXICO - Chihuahua • 4; Municipality of Namiquipa; $28^{\circ} 47^{\prime} 18^{\prime \prime} \mathrm{N}, 107^{\circ} 28^{\prime} 36^{\prime \prime} \mathrm{W}$; elevation 2,121 m a.s.l.; 31 Mar. 2019; obs. F. Álvarez-Córdova; UACH-CF-8182-8185.

Identification. This is the only species of Nasua Storr, 1780 in Chihuahua. The face has a black mask with white markings around the eyes, and a distinctive long, pointed snout; the tail is ringed, long, and is held upright while walking (Gompper 1995).

Distribution. Marginal in southwestern USA; through most of Mexico (except in the dry Mexican Plateau) to Central America and South America (Colombia; Gompper 1995). Recorded habitats in Chihuahua are quebradas and sierras.

Remarks. This species was only recorded at one sampling point in the study area. This species usually moves in groups and prefer harsh terrain such as gorges and forests (Gompper 1995).

\section{Procyon lotor (Linnaeus, 1758)}

Raccoon

Figure 3F

Material examined. MEXICO - Chihuahua - 1; Municipality of Namiquipa; $28^{\circ} 48^{\prime \prime} 33^{\prime \prime} \mathrm{N}, 107^{\circ} 28^{\prime \prime} 02^{\prime \prime} \mathrm{W}$; elevation 2,068 m a.s.1.; 30 Mar. 2019; obs. F. ÁlvarezCórdova - 1; Municipality of Namiquipa, Santa Ana de Babícora, 2904"58"N, 107³1"13"W; elevation 1,018 m 
a.s.1.; 21 Jan. 2015; obs. J. A. Fernández; (Gómez-Valenzuela et al. 2017); UACH-CV-210.

Identification. This is the only species of Procyon Storr, 1780 occurring in Chihuahua. It has a distinctive black mask. The body is thick with a furry, ringed tail (Lotze and Anderson 1979). It can be distinguished from the coati by the shorter snout and tail.

Distribution. Through most of Canada, the USA, and Mexico to Costa Rica and Panama (Lotze and Anderson 1979). Recorded habitats in Chihuahua are quebradas, sierras, and valleys.

Remarks. This species is usually found near water (Lotze and Anderson 1979) where it captures amphibians and invertebrates. This species has been previously recorded in our study area (Municipality of Namiquipa), based on a road-kill individual (Gómez-Valenzuela et al. 2017).

Order Artiodactyla

Family Tayassuidae

\section{Dicotyles tajacu (Linnaeus, 1758)}

Collared Peccary

Figure 3G

Material examined. MEXICO - Chihuahua • 13; Municipality of Namiquipa; $28^{\circ} 46^{\prime} 32^{\prime \prime} \mathrm{N}, 107^{\circ} 27^{\prime} 33^{\prime \prime} \mathrm{W}$; elevation 2,191 m a.s.1.; 18 June, 3 October 2018; obs. F. Álvarez-Córdova - 5; Municipality of Namiquipa; $28^{\circ} 46^{\prime} 42^{\prime \prime} \mathrm{N}, 107^{\circ} 27^{\prime} 45^{\prime \prime} \mathrm{W}$; elevation 2,170 m a.s.1.; 28 September 2018; obs. F. Álvarez-Córdova • 13; Municipality of Namiquipa; $28^{\circ} 47^{\prime} 18^{\prime \prime} \mathrm{N}, 107^{\circ} 28^{\prime} 36^{\prime \prime} \mathrm{W}$; elevation 2,121 m a.s.1.; 29 September, 10 October 2018; obs. F. Álvarez-Córdova - 12; Municipality of Namiquipa; $28^{\circ} 47^{\prime} 49^{\prime \prime} \mathrm{N}, 107^{\circ} 29^{\prime} 02^{\prime \prime} \mathrm{W}$; elevation 2,107 m a.s.l.; 16 October 2019; obs. F. Álvarez-Córdova • 22; Municipality of Namiquipa; $28^{\circ} 52^{\prime} 49^{\prime \prime} \mathrm{N}, 107^{\circ} 27^{\prime} 08^{\prime \prime} \mathrm{W}$; elevation 1,876 m a.s.1.; 20 October 2018; 30 March 2019; obs. F. Álvarez-Córdova; UACH-CF-8186-8250.

Identification. This is the only species of peccary in Chihuahua. It has a pig-like appearance but can be distinguished from European Boar (Sus scrofa Linnaeus, 1758 ) by its small size. It has a coarse fur and a conspicuous white collar around the neck, and the rest of the body is dark gray (Schmidly and Bradley 2016).

Distribution. Southwestern USA, most of Mexico (but not in Baja California and the dry Mexican Plateau), through most of South America (Schmidly and Bradley 2016). Recorded habitats in Chihuahua are quebradas and sierras.

Remarks. This is the only wild pig in this part of the state. In the northeastern parts of Chihuahua, it occurs in sympatry with the exotic European Boar.

\section{Odocoileus virginianus (Zimmermann, 1780)}

White-tailed Deer

Figure $3 \mathrm{H}$

Material examined. MEXICO - Chihuahua - 7; Municipality of Namiquipa; $28^{\circ} 46^{\prime} 32^{\prime \prime} \mathrm{N}, 107^{\circ} 27^{\prime} 33^{\prime \prime} \mathrm{W}$; elevation 2,191 m a.s.1.; 17 August 2018; obs. F. ÁlvarezCórdova - 21; Municipality of Namiquipa; $28^{\circ} 47^{\prime} 18^{\prime \prime} \mathrm{N}$, $107^{\circ} 28^{\prime} 36^{\prime \prime} \mathrm{W}$; elevation 2,121 m a.s.1.; 28 September 2018; obs. F. Álvarez-Córdova • 3; Municipality of Namiquipa; $28^{\circ} 47^{\prime} 30^{\prime \prime} \mathrm{N}, 107^{\circ} 28^{\prime} 49^{\prime \prime} \mathrm{W}$; elevation 2,124 m a.s.1.; 30 September 2018; obs. F. Álvarez-Córdova • 26; Municipality of Namiquipa; $28^{\circ} 27^{\prime} 39^{\prime \prime} \mathrm{N}, 107^{\circ} 29^{\prime} 01^{\prime \prime} \mathrm{W}$; elevation 2,110 m a.s.1.; 22 October 2018, 12 October 2019; obs. F. Álvarez-Córdova - 36; Municipality of Namiquipa; $28^{\circ} 47^{\prime} 49^{\prime \prime} \mathrm{N}, 107^{\circ} 29^{\prime} 02^{\prime \prime} \mathrm{W}$; elevation 2,107 m a.s.1.; 8 October 2018, 8, 13 January 2019; obs. F. Álvarez-Córdova - 59; Municipality of Namiquipa; $28^{\circ}$ $52^{\prime} 49^{\prime \prime} \mathrm{N}, 107^{\circ} 27^{\prime} 08^{\prime \prime} \mathrm{W}$; elevation 1,876 m a.s.1.; 1 October 2018; 5-7 October 2019; obs. F. Álvarez-Córdova; UACH-CF-8251-8402.

Identification. This is the second largest species of its genus in Chihuahua and the only species inhabiting the highlands of the Sierra Madre Occidental. The dorsal color varies from shades of brown to grayish. White fur patches are found on the nose, around the eyes, and under the tail (Smith 1991).

Distribution. Canada, USA, and most of Mexico (but not in Baja California) to northern South America (Smith 1991). Recorded habitats in Chihuahua are quebradas, sierras, valleys, and arid lands.

Remarks. White-tailed Deer occur in most of the forested areas of the state and only marginally the arid regions, where it is replaced by the larger, Mule Deer, Odocoileus hemionus (Rafinesque, 1817) (López-González and García-Mendoza 2012).

\section{Discussion}

There are only a few recent studies documenting the diversity of mammals in general, and of medium-sized and large mammals in particular, in the state of Chihuahua. All species reported in here had already been recorded for the state (Anderson 1972; López-González and García-Mendoza 2012). We recorded 16 species of medium-sized and large mammals in the two habitats in the Rancho Experimental Teseachi. This number corresponds to $50 \%$ of the medium-sized and large mammals reported from Chihuahua by López-González and García-Mendoza (2014). The species that we recorded represent $12 \%$ of the diversity reported for Chihuahua in an area of approximately $5 \%$ of the state.

In the Sierra Madre Occidental region of Chihuahua - where our study area is located - the only studies that have documented mammal diversity are by Sánchez-Mateo et al. (2007) and Medina-Torres et al. (2015). However, both studies reported eight or fewer species of medium-sized and large mammals. Their results are probably biased by available resources and methodologies. Sánchez-Mateo et al. (2007) collected tracks and scat and walked transects for visual, and Medina-Torres et al. (2015) used only five camera traps during two seasons (spring and summer) for two years. Our study 
used a combination of three sampling techniques (camera traps, scent stations, and track and scat collection) through a full year, covering all seasons. We identified at least twice as many species (16 species) than the previous studies; this highlights the usefulness of using several sampling techniques to document the mammal diversity. For example, the camera traps did not detect evidence of Ursus americanus, but scat was collected indicating the presence of this species.

In a study by Rodríguez-Maturino et al. (2020) in Durango, Mexico, in a temperate forest similar to our study area but with a wider area $(16,482 \mathrm{ha})$, the diversity of medium-sized and large mammals was documented using trap cameras for 10 months. These authors reported 10 species, and only one species was not recorded by us: Bassariscus astutus Lichtenstein, 1830 (Ring-tailed Cat). However, some species not reported by Rodríguez-Maturino et al. (2020) were recorded by us using a combination of sampling methods (S. floridanus, M. macroura).

The species accumulation curves show the differences in mammalian diversity between the two types of habitats, with diversity higher in POF $(\alpha=16)$ than in OMG $(\alpha=9)$. Beta-diversity between both ecosystems was $\beta=7$. This difference in mammals can be due to certain species, such as $P$. concolor, M. mephitis, M. macroura, S. gracilis, P. lotor, N. narica, and U. americanus, being more common in forested habitats, as this type of ecosystem provides them food, shelter, and protection (Anderson 1972; López-González and García-Mendoza 2012). In the POF, a track tentatively attributed to the Jaguarundi, Herpailurus yagouaroundi (É. Geoffroy Saint-Hilaire, 1803), was found. However, due to the lack of enough evidence or information about this species in the state and because it was only a single record, it was ommitted until conclusive evidence is found.

All the species in this study $(n=16)$ are classified as Least Concern by the IUCN (2019), meaning that their populations do not require immediate conservationrelated attention. The same applies for NOM-059 (2010), which is the Official Mexican endangered species list. Also, none of the species reported are endemic to Mexico (Ceballos et al. 2005), but most of them show a Nearctic biogeographical affinity (e.g., L. rufus, C. latrans, $U$. americanus) and fewer are Neotropical in origin ( N. narica, D. tajacu).

The mammal information generated for this project will serve as a baseline for the establishment of better management and conservation plans for the Rancho Experimental Teseachi, Chihuahua, Mexico.

\section{Acknowledgements}

We thank the three anonymous referees and the associate editor, G. Garbino, who kindly reviewed earlier versions of this manuscript; the CONABIO (Comision Nacional para el Conocimiento y Uso de la Biodiversidad) and CONANP (Comisión Nacional de Areas Naturales
Protegidas) for financial support through Project PJ006 granted to JAF; the administrative authorities of the Facultad de Zootecnia y Ecología, Universidad Autónoma de Chihuahua for kindly allowing us access to the study site. We also thank B.Y. Cruz-Garibaldi and J. Sandoval, for their help with fieldwork, and A. González who kindly provided us with the image of the Black Bear (PAPIITIN212217-UNAM). FAC thanks the Consejo Nacional de Ciencia y Tecnologia, México, for the support of the master's scholarship (2018-000012-01NACF-08530).

\section{Authors' Contributions}

FAC and JAF designed the study; FAC collected the data; FAC and JAF conducted the analyses; FAC identified the species and FAC and JAF wrote the manuscript.

\section{References}

Álvarez-Córdova F, Fernández JA, Martínez-Salazar EA, RosasValdez R (2019) First record of the genus Physaloptera sp. (Nemata: Physalopteridae) in scats from Coyote, Canis latrans in Chihuahua, México. Therya 10 (2): 183-185. https://doi.org/10.12933/ therya-19-799

Anderson S (1972) Mammals of Chihuahua, taxonomy and distribution. Bulletin of the American Museum of Natural History 148: 153-398.

Aranda N (2000) Huellas y otros rastros de los mamíferos grandes y medianos de México. Instituto de Ecología A.C., Xalapa, Veracruz, México, 212 pp.

Arévalo EJ (2001) Manual de campo para el monitoreo de mamíferos terrestres en áreas de conservación. Asociación Conservacionista de Monteverde, San José, Costa Rica, 18 pp.

Bekoff M (1977) Canis latrans. Mammalian Species 79: 1-9. https:// doi.org/10.2307/3503817

Best TL (1996) Lepus californicus. Mammalian Species 530: 1-10. https://doi.org/10.2307/3504151

Ceballos G, Arroyo-Cabrales J, Medellín RA, Domínguez-Castellanos Y (2005) Lista actualizada de los mamíferos de México. Revista Mexicana de Mastozoología 9: 21-71.

Chapman JA, Hockman JG, Ojeda MM (1980) Sylvilagus floridanus. Mammalian Species 136: 1-8. https://doi.org/10.2307/3504055

Colwell RK (2004). EstimateS: statistical estimation of species richness and shared species from samples. Version 7.5. http://purl. oclc.org/estimates.

Comisión Técnico Consultiva para la Determinación Regional de los Coeficientes de Agostadero (COTECOCA) (1978) Secretaría de Agricultura y Recursos Hidráulico. Subsecretaría de Ganadería, Secretaría de Agricultura y Recursos Hidráulicos, Chihuahua, México. Diario Oficial de la Federación 30/08/1978.

Currier MJP (1983) Felis concolor. Mammalian Species 1983: 1-7. https://doi.org/10.2307/3503951

Dragoo JW, Honeycutt RL, Schmidly DJ (2003) Taxonomic status of white-backed hog-nosed skunks, genus Conepatus (Carnivora: Mephitidae). Journal of Mammalogy 84: 159-176. https://doi.org/ 10.1644/1545-1542(2003)084<0159:tsowbh>2.0.co;2

Dragoo JW, Sheffield SR (2009) Conepatus leuconotus (Carnivora: Mephitidae). Mammalian Species 827: 1-8. https://doi.org/10.16 44/827.1

Fernández-González AM, Kosoy MY, Rubio AV, Graham CB, Montenieri JA, Osikowicz L, Bai M, Acosta-Gutiérrez R, Ávila-Flores R, Gage KL, Suzán G (2016) Molecular survey of Bartonella species and Yersinia pestis in rodent fleas (Siphonaptera) from Chihuahua, Mexico. Journal of Medical Entomology 53 (1): 199-205. https://doi.org/10.1093/jme/tjv181 
Fritzell EK, Haroldson KJ (1982) Urocyon cinereoargenteus. Mammalian Species 189: 1-8. https://doi.org/10.2307/3503957

Gómez-Valenzuela C, Flores-Zamarripa FJ, Fernández JA (2017) Nuevos registros para el mapache Procyon lotor (Carnivora: Procyonidae) y el tlalcoyote, Taxidea taxus (Carnivora: Mustelidae) en Chihuahua y Durango, México. Acta Zoológica Mexicana 33: 394-397.

Gompper ME (1995) Nasua narica. Mammalian Species 487: 1-10. https://doi.org/10.2307/3504195

Hernández-Urbina CF, Vital-García C, Escárcega AM, Gatica A, Sánchez-Olivas MP, Clemente-Sánchez F (2020) First report of Siphonaptera parasites in Canis latrans in the Flora and Fauna Protection Area, Médanos de Samalayuca Chihuahua, Mexico. Veterinary Parasitology: Regional Studies and Reports 20: 1-3. https://doi.org/10.1016/j.vprsr.2020.100379

Hoffmann A, Decher J, Rovero F, Schaer J, Voigt C, Wibbelt G (2010) Field methods and techniques for monitoring mammals. In: Eymann J, Degreef J, Hauser C, Monje JC, Samyn Y, VandenSpiegel $\mathrm{D}$ (Eds.) Manual of field recording techniques and protocols for all taxa biodiversity inventories and monitoring. Abc Taxa 8: 482-529.

Hwang YT, Larivière S (2001) Mephitis macroura. Mammalian Species 686: 1-3. https://doi.org/10.2307/0.686.1

INEGI (Instituto Nacional de Estadística, Geografía e Informática) (2005) Marco Geoestadístico 2005 versión 5.0. http://inegi.org.mx/ geo/contenidos/geoestadistica/M_Geoestadistico.aspx. Accessed on: 2019-9-29.

IUCN (2019) The IUCN Red List of Threatened Species. Version 2019-2. http://www.iucnredlist.org. Accessed on: 2019-10-11.

Larivière S (2001) Ursus americanus. Mammalian Species 647: 1-11. https://doi.org/10.2307/0.647.1

Larivière S, Walton LR (1997) Lynx rufus. Mammalian Species 563: 1-8. https://doi.org/10.2307/3504533

Lee DN, Pfau RS, Ammerman LK (2010) Taxonomic status of the Davis Mountains Cottontail, Sylvilagus robustus, revealed by amplified fragment length polymorphism. Journal of Mammalogy 91: 1473-1483. https://doi.org/10.1644/09-MAMM-A-382.1

López-González C, García-Mendoza D (2012) A checklist of the mammals (Mammalia) of Chihuahua, Mexico. Check List 8 (6) 1122-1133. https://doi.org/10.15560/8.6.1122

López-Pérez AM, Gage K, Rubio AV, Montenieri J, Orozco L, Suzan G (2018) Drivers of flea (Siphonaptera) community structure in sympatric wild carnivores in northwestern Mexico. Journal of Vector Ecology 43 (1): 15-25. https://doi.org/10.1111/jvec.12278

López-Pérez AM, Osikowicz L, Bai Y, Montenieri J, Rubio A, Moreno K, Susan G, Kosoy M (2017) Prevalence and phylogenetic analysis of Bartonella species of wild carnivores and their fleas in northwestern Mexico. EcoHealth 14 (1): 116-129. https://doi.org/10. 1007/s10393-017-1216-2

López-Pérez AM, Sánchez-Montes S, Foley J, Guzmán-Cornejo C, Colunga-Salas P, Pascoe E, Becker I, Delgado-de la Mora J, Licona-Enriquez JD, Suzan G (2019) Molecular evidence of Borrelia burgdorferi sensu stricto and Rickettsia massiliae in ticks collected from a domestic-wild carnivore interface in Chihuahua, Mexico. Ticks Tick Borne Disease 10: 1118-1123. http://doi.org/ 10.1016/j.ttbdis.2019.05.018

Lotze JH, Anderson S (1979) Procyon lotor. Mammalian Species 119: 1-8. https://doi.org/10.2307/3503959

Loveless AM, Reding DM, Kapfer PM, Papeş M (2016) Combining ecological niche modelling and morphology to assess the rangewide population genetic structure of bobcats (Lynx rufus). Biological Journal of the Linnean Society 117: 842-857. https://doi org $/ 10.1111 /$ bij. 12718

Medina-Torres SM, Gastélum-Vizcarra EL, Lara-Ponce E, PiñaRuiz HH (2015) Inventario participativo de mamíferos silvestres en el ejido San Ignacio, municipio de Morelos, Chihuahua. Acta Zoológica Mexicana 31: 221-233.

Oaks EC, Young PJ, Kirkland GL, Schmidt DF (1987) Spermophilus variegatus. Mammalian Species 272: 1-8. https://doi.org/10.2307/ 3503949

Pacheco J, Ceballos G, List R(2000)Los mamíferos de la región de JanosCasas Grandes, Chihuahua, México. Revista Mexicana de Mastozoología 4: 69-83. https://doi.org/10.22201/ie.20074484e.1999. 4.1.82

Pérez-Amezola MC, Gatica-Colima AB, Cuevas-Ortalejo DM, Martínez-Calderas JM, Vital-García C (2020) Biota ribereña del Área de Protección de Flora y Fauna Canon de Santa Elena México. Revista Bio Ciencias 7: 1-22.

Phuong MA, Lim MCW, Wait DR, Rowe KC, Moritz C (2014) Delimiting species in the genus Otospermophilus (Rodentia: Sciuridae), using genetics, ecology, and morphology. Biological Journal of the Linnean Society 113: 1136-1151. https://doi.org/10.1111/ bij. 12391

Ramírez-Pulido J, González-Ruiz N, Gardner AL, Arroyo-Cabrales J (2014) List of Recent land mammals of Mexico. Special Publications of the Museum of Texas Tech University 63: 1-69.

Rodriguez-Maturino A, Viggers-Carrasco MG, Morales-Balderas BN, López-Reyes JA, Silva-Flores R, De León-Mata GD (2020) Solapamiento en los patrones de actividad de mamíferos y sus presas potenciales en un área de la Sierra Madre Occidental en Durango, México. Bio Ciencias 7: 1-18. https://doi.org/10.15741/rev bio.07.e962

Sánchez-Cordero V, Botello F, Flores-Martínez JJ, Gómez-Rodríguez RA, Guevara L, Gutiérrez-Granados G, Rodríguez-Moreno Á (2014) Biodiversidad de Chordata (Mammalia) en México. Revista Mexicana de Biodiversidad 85 (S1): 496-504. https://doi. org $/ 10.7550 / \mathrm{rmb} .31688$

Sánchez-Mateo MA, Soto CR, Lebgue T (2007) Diversidad de aves y mamíferos en zonas donde anida Rhynchopsitta pachyrhyncha, en el municipio de Madera, Chihuahua, México. Revista Latinoamericana de Recursos Naturales 3: 52-57.

SEMARNAT (2010) Norma Oficial Mexicana NOM-059-SEMARNAT-2010, Protección ambiental-Especies nativas de México de flora y fauna silvestres-Categorías de riesgo y especificaciones para su inclusión, exclusión o cambio-Lista de especies en riesgo. Diario Oficial de la Federación, 110.

Scheick BK, McCown W (2014) Geographic distribution of American Black Bears in North America. Ursus 25 (1): 24-33. https://doi. org/10.2192/ursus-d-12-00020.1

Schmidly DJ, Bradley RD (2016) The mammals of Texas, 7th edition. The University of Texas Press, Austin, USA, $694 \mathrm{pp}$.

Smith WP (1991) Odocoileus virginianus. Mammalian Species 388: 1-13. https://doi.org/10.2307/3504281

Trolliet F, Huynen MC, Vermeulen C, Hambuckers A (2014) Use of camera traps for wildlife studies. A review. Biotechnology, Agronomy and Society and Environment 18: 446-454.

Van Gelder RG (1959) A taxonomic revision of the spotted skunks (genus Spilogale). Bulletin American Museum of Natural History 117: 229-392.

Verts BJ, Carraway LN, Kinlaw A (2001) Spilogale gracilis. Mammalian Species 674: 1-10. https://doi.org/10.2307/0.674.1

Wade-Smith J, Verts BJ (1982) Mephitis mephitis. Mammalian Species 173: 1-7. https://doi.org/10.2307/3503883 